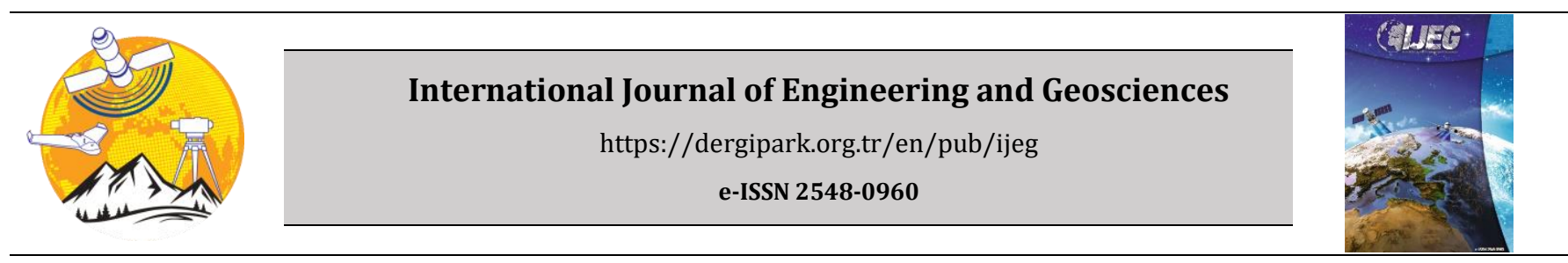

\title{
Using multiple linear regression to analyze changes in forest area: the case study of Akdeniz Region
}

\author{
Neşe Başaran 1(D), Dilek Küçük Matcı *1(D), Uğur Avdan 1 (i) \\ ${ }^{1}$ Eskisehir Technical University, Institute of Earth and Space Sciences Institute, Eskisehir, Turkey
}

\author{
Keywords \\ Remote sensing \\ Google Earth Engine \\ Forest areas changes \\ Statistical Analyze
}

\begin{abstract}
Forest area losses are one of the most significant changes in land cover. These losses negatively affect ecosystems and cause severe economic and social life problems. It is necessary to monitor the process carefully and analyze the effects well to minimize all these negative effects in forest land losses and improve the development in urban areas positively. It is of great importance that these analyses are carried out quickly and accurately in terms of developing the natural environment. In this study, the effects that cause forest losses in the Mediterranean Region over the years are examined with the data obtained with the Google Earth Engine (GEE). Within the scope of the study, the changes in forest areas in the Mediterranean Region between 2004 and 2019 have been examined by considering many factors. In the study, Normalized Difference Vegetation Index (NDVI), precipitation, temperature, land surface temperature, aerosol optical depth, ozone, fire, urban areas, and population data were obtained with GEE. The data obtained were analyzed statistically, and the factors affecting the losses in forest areas the most were determined.
\end{abstract}

\section{INTRODUCTION}

Forests are among the critical natural resources for all the living creatures. Considering the climatic and environmental factors, losses in forest areas negatively affect ecosystems and cause severe problems in economic and social life. It is essential to carefully monitor the changes in forest areas, determine the effects that cause these changes, and make correct plans for the future. There are studies investigating the climatic and socio-economic factors that cause forest losses (Fearnside, 1995; Loreau et al., 2001). The effects of desertification/land degradation, erosion, and drought are gradually increasing together with climate change and human activities, which are one of these factors. Erosion in agriculture, forest and pasture areas as a result of improper land use; destruction, decrease, or loss of productivity in agricultural and pasture lands; destruction of natural ecosystems such as forests, wetlands, steppes and biodiversity loss; The unintended use of fertile agricultural and pasture lands and improper utilization, rapid population growth and the harmful effects of urbanization are the main facts (Gasparri \& Grau, 2009; Roces-Díaz et al., 2018). As a result of land degradation, there is a decrease or loss of productivity not only in production areas such as agricultural lands and pastures but also in natural areas such as forests, wetlands, steppes, and scrub/shrubbery, biologically, ecologically, and economically (TOB, 2019).

The population increase, which is claimed to cause forest loss, leads to increasing land demands, thus accelerating the urbanization process. This increase has many consequences and has negative results on land cover (Şen, et. al., 2018). Many factors, such as environmental pollution and changes in climate conditions, cause a decrease in forest areas due to the deterioration of the natural balance (DeFries, et al., 2010; $\mathrm{Yu}$, et. al., 2019). This process should be followed to 
minimize the negative effects of these changes and plan urbanization correctly. The investigation of land changes is of great importance in terms of protecting natural areas and preventing forest losses (Atmış \& Günșen, 2016).

Air pollution poses a threat to forests and causes losses (Andrée, et al., 2019). Harmful particles in the atmosphere damage forests, react with water particles and cause acid rain. Acid rain has the most significant impact on the forest (Dündar, et. al., 2015). In another study, it was revealed that forest losses had been experienced in the past years due to intense air pollution around the Muğla and Gökova Thermal Power Plants (Tolunay, 2013).

Considering the effects of climatic characteristics on forest changes, it causes the drying of trees due to effects such as excessive drought and thirst and the occurrence of forest fires, resulting in a decrease in forest areas (Desbureaux \& Damania, 2018; Tolunay, 2015).

Developments in remote sensing and geographic information systems have enabled detailed investigations using high-resolution data. These developments have also enabled the data to be obtained numerically, reach the user quickly, and effectively use the data. These data were used in counting trees (Ocer, et. al., 2020), determining burnt forest areas (Çömert, et al., 2019; Demir, 2020; Matcı \& Avdan, 2020), land cover classifications (Ahady \& Kaplan 2022), air pollution investigations(Kaplan \& Avdan, 2020), land surface temperature monitoring (Orhan, et. al., 2019) and investigating urban growth to determine the tree stock, etc.

Monitoring forest areas with satellite images is one of the methods used in the literature. For example, Schepaschenko et al. (2015) analyzed the forest inventory in Russia using twelve different satellite datasets. As a result of the study, it was stated that the official forest inventory data was incorrect and needed to be updated (Schepaschenko et al., 2015). In another study to examine the spatiotemporal change of forest areas, the change of forests in Taita Hills, Kenya was examined with aerial images (Pellikka, et. al., 2009). In another study, the change of forest areas in Moncayo Natural Park was examined using Landsat images (del Castillo, et. al., 2015). Hansen Global Forest Change data, a data set obtained from satellite images, was used to determine the effects of deforestation on the International Union for Conservation of Nature (Betts et al., 2017).

In parallel with the developments in remote sensing, GEE, which offers the opportunity to research by combining large satellite images and data obtained from satellites, has been providing users with significant advantages in recent years. Access to large data sets has been made easy with GEE. It contains many data sets such as environment, climate, land cover, geology, population, disease, and disaster. This large data set provides fast and effective performance of many studies such as change analysis and ease of use. In one of these studies, random forest (RF), support vector machine
(SVM), classification, and regression tree (CART) algorithms were applied using Sentinel-2-time series to map a natural conservation area in Calabria (Southern Italy) in the study conducted in 2020. In this study using GEE, high accuracy has been obtained, and it has been proven that GEE is a reliable and powerful tool for the classification process (Praticò, et. al., 2021). In a study conducted in 2020, the changes resulting from forest fires in Australia between 2019-2020 were followed. NDVI analysis was performed using Landsat-8 and Landsat-5 images via GEE, and the damaged areas were examined (Demir, 2020).

The increase in forest losses in the Mediterranean Region in recent years is becoming remarkable. Accordingly, in this study, the reasons were investigated by monitoring the changes in the forest areas in the Mediterranean region between the years 2004-2019 with GEE. To the best of our knowledge, this study is the first to examine forest area changes in the entire Mediterranean region using remote sensing data. The findings of this study will provide a way for local authorities and decision-makers to monitor forest dynamics in near real-time and analyze how trends will evolve in the future.

\section{STUDY AREA and MATERIALS}

Mediterranean Coast, extends along the Mediterranean coast of southern Turkey, has $89493 \mathrm{~km}^{2}$. The Aegean Region is located to the west and northwest, the Central Anatolia Region to the north, and the Southeastern Anatolia Region to the east. Its width varies between $120-180 \mathrm{~km}$. The length of the coast is 1542 kilometers from the Syrian border in the east to Marmaris in the west.

The Mediterranean climate is seen in the region, which has a mountainous and rugged terrain. Summers are hot and dry in this climate. Winters are warm and rainy, and there is no significant difference between the amount of rainfall in summer and winter (Sari, 2021). The terrestrial climate is observed towards the inner parts. The annual average temperature is $18-20 \mathrm{C}^{\circ}$ on the coast and 12-14 $\mathrm{C}^{\circ}$ on the interior (Doğaner, 2015). The map of the study area is given in Figure 1.

This study aims to monitor the change in forest areas, analyze and evaluate the factors that are thought to cause the change, and investigate the impact rates. In this direction, satellite images and algorithms for the factors that are stated to cause changes in the literature were obtained using GEE. The numerical data obtained for each element were evaluated with the help of the linear regression statistical method, and its effect on the losses in forest areas was investigated. For the study, the data between the years 2004-2019 were analyzed. Annual averages are calculated based on daily data.

The data used in the study were obtained from images obtained from different satellites using the GEE. The characteristics of the data used in the study are shown in Table 1. 


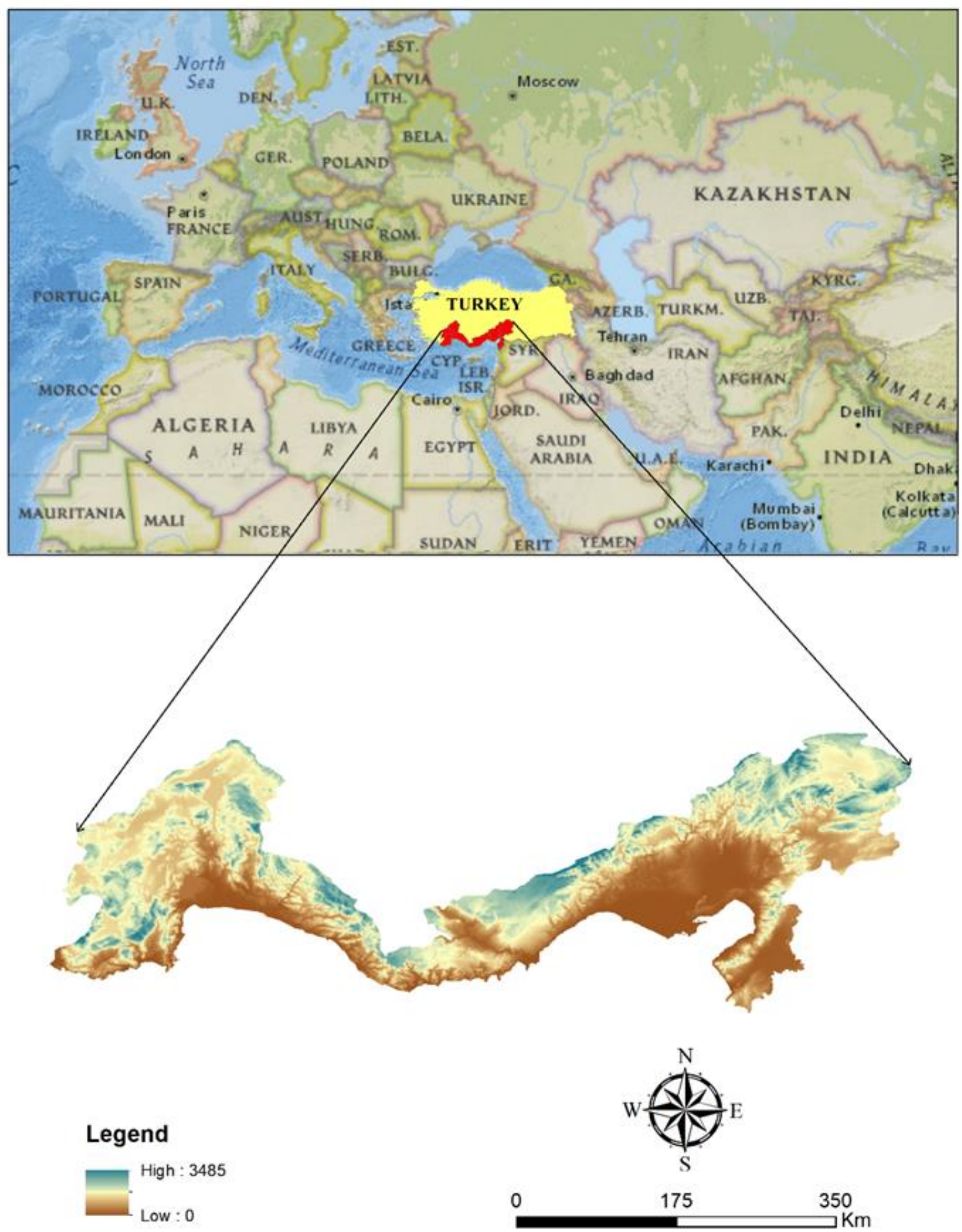

Figure 1. Study area

\subsection{NDVI data}

NDVI data obtained through MODIS Terra Satellite MOD13A1.006 Vegetation Index were used in the study to determine the green areas. NDVI is the normalized value obtained by subtracting the near-infrared and red wavelength light values from each other and dividing by the sum of the two bands. In the study, NDVI data were obtained from MOD13A1 v6 Terra Vegetation Index in the GEE data set.

\subsection{Precipitation data}

In the study, precipitation data were obtained from CHIRPS (rain gauge and rain forecast from satellite observations) station observations. CHIRPS was created in collaboration with the USGS (United States Geological Research Unit) and EROS (World Resources Observation and Science Center) to provide up-to-date datasets for trend analysis and drought monitoring (Funk et al., 2015). 
Table 1. Data used in the study

\begin{tabular}{|c|c|c|}
\hline Data & Dataset Availability & Dataset Provider \\
\hline NDVI & 2000-02-18- 2021-01-01 & $\begin{array}{l}\text { MODIS MOD13Q1.006 Terra Vegetation Indices NDVI } \\
\text { Data (16 Days-Global) }\end{array}$ \\
\hline Precipitation & $1981-01-01-2020-12-26$ & $\begin{array}{l}\text { CHIRPS Pentad: Station Data and Climate Hazards Group } \\
\text { Infrared Precipitation Data }\end{array}$ \\
\hline Temperature & 1979-01-02 - 2020-07-09 & $\begin{array}{l}\text { Copernicus Climate Change Service - ERA 5-Day } \\
\text { Temperature Data }\end{array}$ \\
\hline $\begin{array}{l}\text { Terrestrial } \\
\text { Temperature }\end{array}$ & $2000-03-05-2021-01-28$ & $\begin{array}{l}\text { MODIS MOD11A1.006 Daily Land Surface Temperature } \\
\text { Data (Daily-Global) }\end{array}$ \\
\hline Aerosol & $2000-03-01-2021-11-01$ & $\begin{array}{l}\text { MODIS MOD08_M3.061 Terra Atmosphere Aerosol Data } \\
\text { (Monthly-Global) }\end{array}$ \\
\hline Ozone & $1978-01-11-2021-01-28$ & Total Ozone Mapping Spectrometry Data \\
\hline Population & 2000-01-01 - 2021-01-01 & $\begin{array}{l}\text { International Center for Earth Sciences Information } \\
\text { Network-NASA SEDAC GPW } 411 \text { Adjusted Population } \\
\text { Density Data }\end{array}$ \\
\hline Forest Losses & $2000-01-01-2020-01-01$ & Hansen Global Forest Change v1.7 data \\
\hline Forest Fire Data & 2004-11-01 - 20-01-01 & Forest Management Department \\
\hline
\end{tabular}

\subsection{Temperature and land surface temperature data}

The temperature data used in the study were obtained through ERA5. ERA5 is the fifth generation ECMWF re-analysis for global climate and weather for the past 4 to 7 decades. ECMWF is the unit that provides the Copernicus Climate Change service of the European Union Copernicus Earth Observation Program. With the re-analysis method, observation data from many parts of the world are combined into a data set wholly and consistently. In this method, called data assimilation, new observations are suitably combined with previous estimates every twelve hours. The 2-meter temperature data parameters are the air temperature $2 \mathrm{~m}$ above the land, sea, and inland water surfaces. The $2 \mathrm{~m}$ temperature is calculated by interpolation, considering atmospheric conditions (Hersbach et al., 2018).

Land Surface Temperature (LST) makes predictions using algorithms produced by the National Meteorological Center (NMC). Land surface temperatures result from surface-atmosphere interactions and are essential in examining the greenhouse effect. These data are provided by the MOD11A2 V6 product. MOD11A2 V6 is a MODIS product that provides soil land surface temperature data. In the study, the daytime land surface temperature band (LST_Day_1km) of the MOD11A2 V6 product was used. Raw field data received from satellites are processed and presented to the user (Wan, 1999).

\subsection{Aerosol data}

Studies carried out in the past years, and the actual situations show that air pollution causes severe forest losses. In this context, AOD measurements have been examined over the years. The MOD08_M3 V6.1 product is a dataset containing average values of atmospheric parameters (Platnick, et. al., 2017). In the study, the average daily aerosol optical thickness band of MOD08_M3 V6.1 product for land and ocean was used.

\subsection{Ozone data}

Total Ozone Mapping Spectrometer (TOMS) data were used in the study. Total Ozone Mapping Spectrometer (TOMS) data, produced by NASA's
Goddard Flight Center Atmosphere Laboratory, represents 25 years of total ozone data. The world average is $300 \mathrm{DU}$; looking at the years between 2000 to 2019 , study results were calculated as the average of Turkey 318 DU.

\subsection{Population data}

Population data was obtained from Turkish Statistical Institute (TUIK) data. The main task of the TUIK is to compile, produce, publish and distribute data and information in the fields needed by the country. TUIK collects data from individuals, households and workplaces through surveys and censuses. It analyzes the collected data and transforms it into statistical information. This statistical information are reliable guides in the decision-making stages of all segments of the society. In addition, it reports the monitoring and evaluation of the activities in the program by preparing the Official Statistics Program, which includes information about which definition, method, scope and classification will be used by which institution, how often, and how often the data will be compiled and published (TUIK, 2021).

\subsection{Forest Loss data}

For the analysis of forest area losses, the Hansen Global Forest Change data was used. In this data, changes in forest areas were investigated by using Landsat images with time series analysis. 'Loss of Forest Cover' is defined as the transition from forest to deforested state (Hansen, et al. 2013).

The information such as fire event dates, burned area size, and location about the burned forests was obtained from the General Directorate of Forestry's official page. This data set includes forest data and fire statistics from 1937 to the present in Turkey (OGM, 2020).

\subsection{Multiple Linear Regression}

Multiple linear regression analysis was used to statistically analyze the results obtained in the last stage of the study. The analysis is necessary to make sense of and interpret the results obtained in studies and to 
observe the relationships between variables. The regression analysis is a method used to understand the relationship between more than one variable. In the regression analysis, there must be at least one dependent and one independent variable. The analysis of how more than one independent variable affects a dependent variable is done with a multiple regression model (Avdan, et al. 2021). In linear regression, the variable to be determined, namely the dependent variable, must be continuous or sequential numerical data; should not be a categorical variable. On the other hand, it is preferable for the independent variables to be numerical, but in some cases they can also be categorical, such as gender (Khorrami, et. al., 2019).

\section{METHOD}

The aim of the study is to monitor the change in forest areas, to analyze and evaluate the factors thought to cause the change and to investigate the impact rates. For this purpose, the data of the factors thought to cause change were obtained using GEE. GEE is the geospatial data processing platform and works in cloud environment. GEE provides a lot of data on a global scale over the last 40 years. All archives of Landsat and Sentinel images can be accessed easily and simultaneously. The GEE application program interface (API) provides the opportunity to develop with JavaScript and Python coding languages, and to access and apply data at petabyte scale (Koskinen et al., 2019; Xiong et al., 2017).

After the data were obtained, the second stage of the study was started. In this stage, the relationship between the factors was evaluated with the help of multiple linear regression statistical method. In this direction, data between 2004 and 2019 were analyzed. In this direction, data between 2004-2019 were analyzed the NDVI, precipitation, temperature, land surface temperature, aerosol optical depth, ozone, population, forest fires, forest losses data. Then, the independent and the dependent variables determined to use multiple regression method. The work flow used in this study is shown in Figure 2.

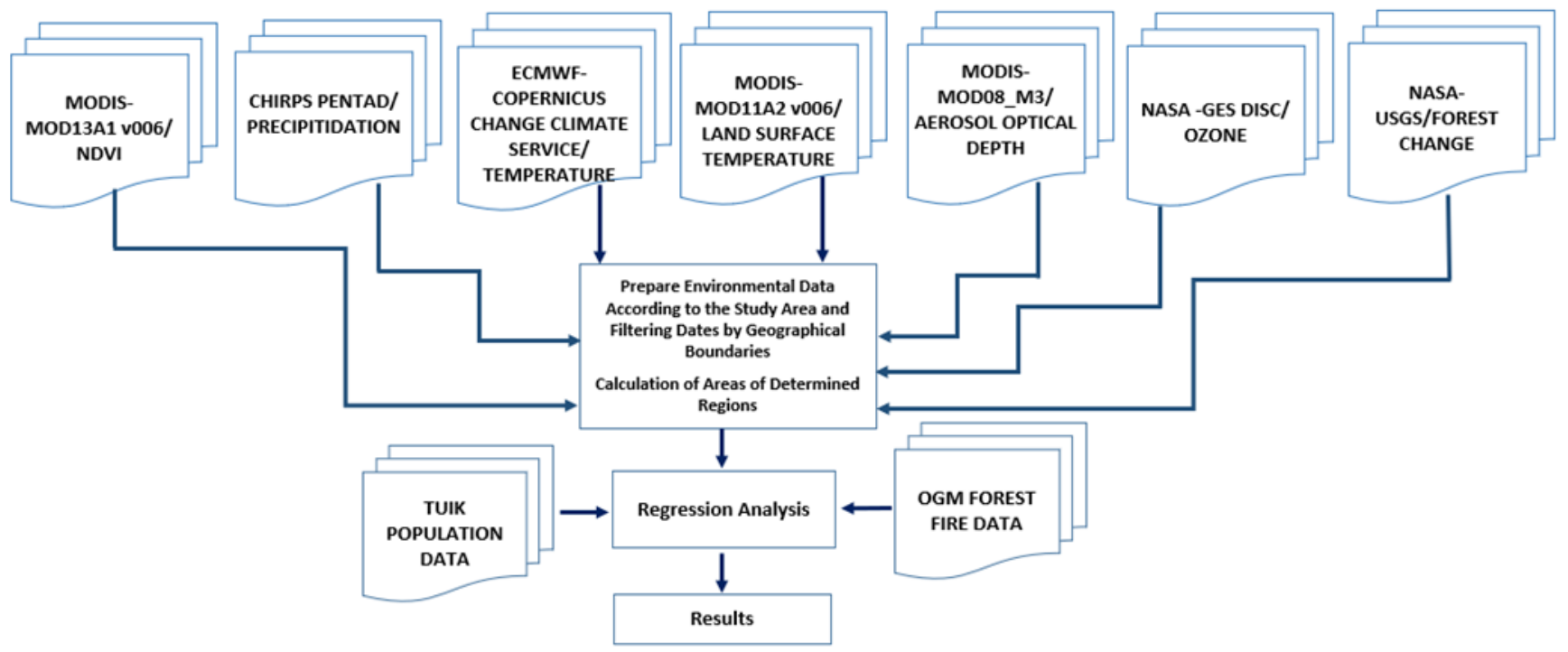

Figure 2. Workflow diagram

\section{RESULTS}

This section presents the obtained data between 2004 and 2019 with numerical and graphic data.

\subsection{Analysis of NDVI values}

It is observed that while NDVI values increase in March, April and May, it decreases in December, January, and February. In Table 2, the changes in NDVI values obtained by years and months are shown.

According to the data obtained in the study, the average NDVI value between 2004-2019 is 0.38. The graph of yearly mean of NDVI values between 2000-2019 is shown in Figure 3.
When the obtained results are analyzed, it is seen that there is no significant decrease trend in NDVI values in the 15-year period. In Figure 4 average NDVI value map of 2010 is given.

\subsection{Analysis of precipitation values}

As a result of the analysis carried out between 2004 and 2019 , it is observed that the precipitation values decreased significantly in the summer months but increased in the winter months. Table 3 shows the amount of precipitation per $\mathrm{mm}$. According to the data obtained, it was seen that the max rainfall was seen in December of 2012 and the minimum rainfall was seen in August 2010.

The graph of yearly mean precipitation values between 2000-2019 is shown in Figure 5. 
Table 2. Obtained NDVI Values

\begin{tabular}{lllllllllllll}
\hline & Jan & Feb & March & Apr & May & Jun & Jul & Aug & Sep & Oct & Nov & Dec \\
\hline 2004 & 0,25 & 0,25 & 0,33 & 0,37 & 0,40 & 0,38 & 0,36 & 0,35 & 0,34 & 0,34 & 0,34 & 0,31 \\
2005 & 0,28 & 0,28 & 0,36 & 0,39 & 0,40 & 0,38 & 0,36 & 0,35 & 0,35 & 0,35 & 0,34 & 0,33 \\
2006 & 0,32 & 0,29 & 0,36 & 0,42 & 0,41 & 0,37 & 0,36 & 0,34 & 0,35 & 0,36 & 0,38 & 0,36 \\
2007 & 0,33 & 0,27 & 0,36 & 0,40 & 0,41 & 0,37 & 0,35 & 0,35 & 0,33 & 0,34 & 0,36 & 0,33 \\
2008 & 0,32 & 0,28 & 0,35 & 0,40 & 0,42 & 0,37 & 0,34 & 0,33 & 0,35 & 0,37 & 0,37 & 0,36 \\
2009 & 0,32 & 0,29 & 0,36 & 0,41 & 0,43 & 0,39 & 0,37 & 0,36 & 0,36 & 0,36 & 0,39 & 0,39 \\
2010 & 0,36 & 0,35 & 0,40 & 0,44 & 0,43 & 0,40 & 0,38 & 0,36 & 0,36 & 0,37 & 0,38 & 0,36 \\
2011 & 0,27 & 0,25 & 0,29 & 0,37 & 0,46 & 0,42 & 0,39 & 0,37 & 0,37 & 0,39 & 0,41 & 0,40 \\
2012 & 0,35 & 0,38 & 0,41 & 0,45 & 0,47 & 0,41 & 0,38 & 0,37 & 0,36 & 0,37 & 0,37 & 0,36 \\
2013 & 0,35 & 0,38 & 0,41 & 0,45 & 0,47 & 0,41 & 0,38 & 0,37 & 0,36 & 0,37 & 0,37 & 0,36 \\
2014 & 0,35 & 0,35 & 0,39 & 0,43 & 0,45 & 0,41 & 0,39 & 0,37 & 0,38 & 0,40 & 0,41 & 0,43 \\
2015 & 0,32 & 0,34 & 0,38 & 0,43 & 0,46 & 0,45 & 0,41 & 0,39 & 0,39 & 0,39 & 0,40 & 0,39 \\
2016 & 0,33 & 0,35 & 0,37 & 0,43 & 0,45 & 0,42 & 0,39 & 0,37 & 0,37 & 0,37 & 0,37 & 0,32 \\
2017 & 0,23 & 0,27 & 0,33 & 0,41 & 0,46 & 0,44 & 0,40 & 0,38 & 0,39 & 0,39 & 0,40 & 0,42 \\
2018 & 0,39 & 0,38 & 0,45 & 0,47 & 0,48 & 0,45 & 0,41 & 0,40 & 0,39 & 0,39 & 0,41 & 0,39 \\
2019 & 0,28 & 0,33 & 0,38 & 0,43 & 0,46 & 0,45 & 0,43 & 0,41 & 0,41 & 0,41 & 0,41 & 0,41 \\
\hline
\end{tabular}

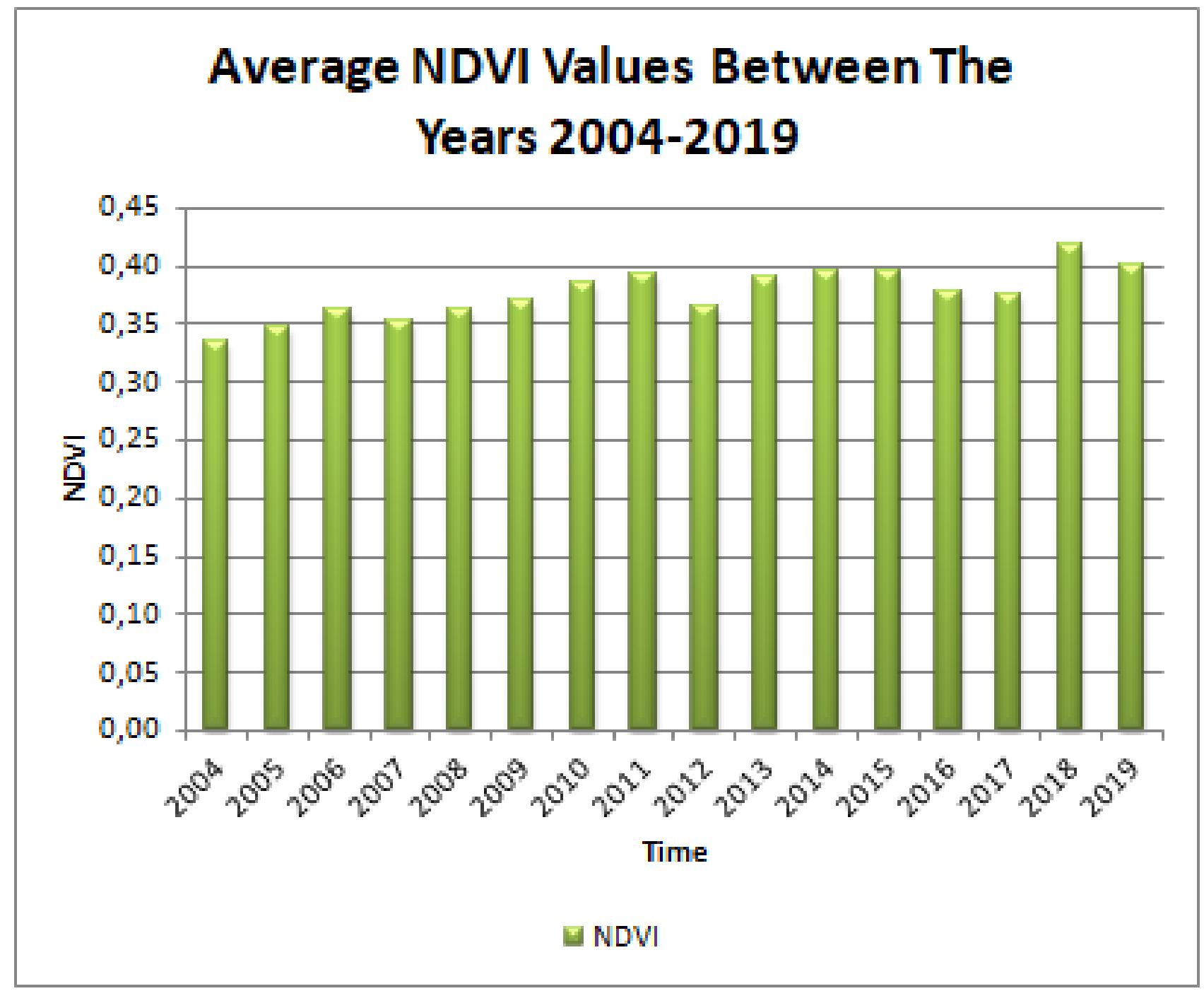

Figure 3. NDVI values between 2004-2019 


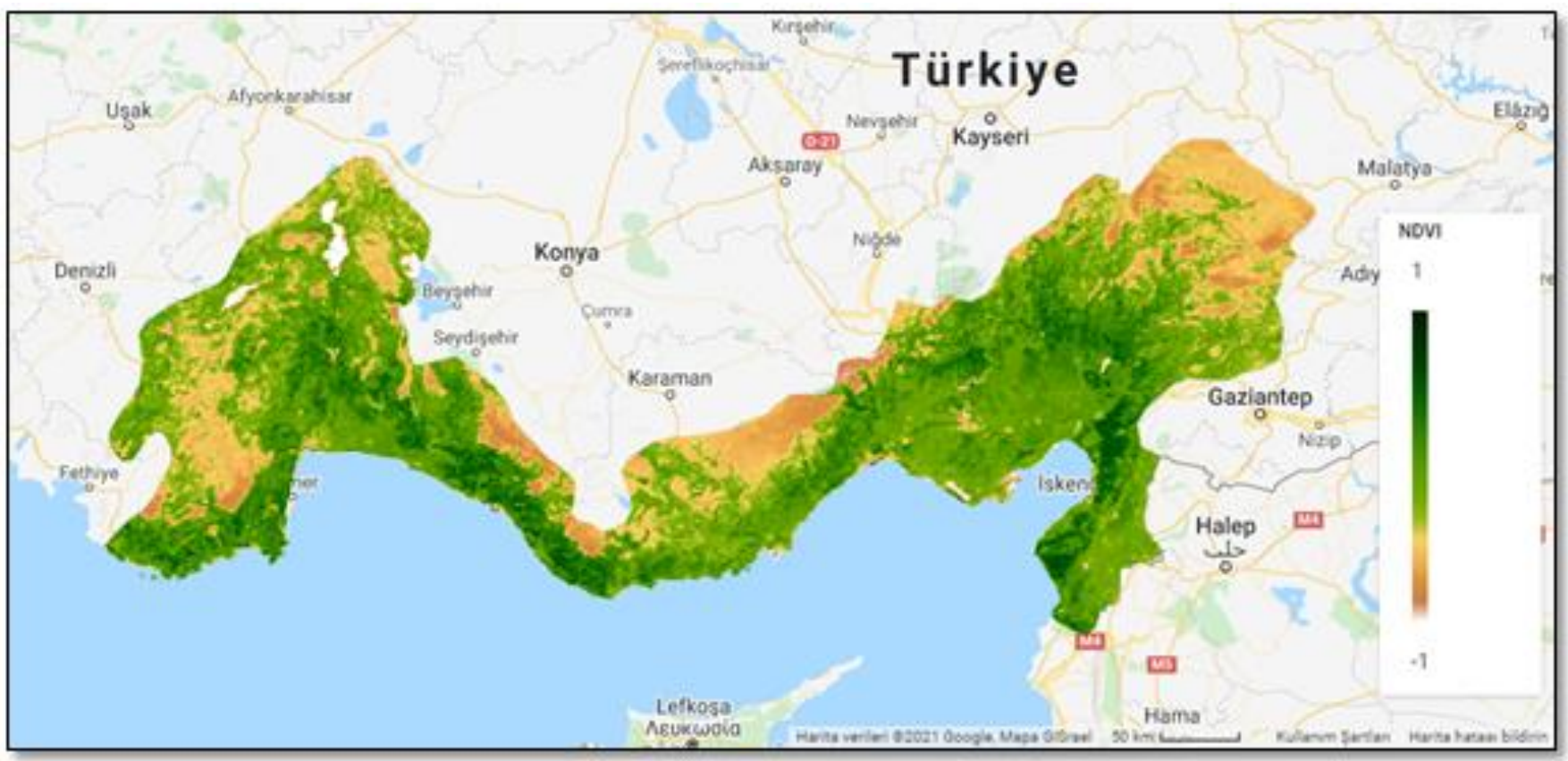

Figure 4. Average NDVI values map of 2010

Table 3. Monthly precipitation data

\begin{tabular}{ccccccccccccc}
\hline & Jan & Feb & March & Apr & May & Jun & Jul & Aug & Sep & Oct & Nov & Dec \\
\hline 2004 & 229,45 & 99,73 & 41,62 & 58,49 & 28,08 & 12,23 & 6,16 & 4,53 & 7,54 & 26,21 & 131,95 & 74,13 \\
2005 & 139,26 & 79,94 & 74,27 & 51,56 & 36,07 & 23,66 & 7,11 & 4,98 & 20,24 & 36,67 & 99,94 & 85,10 \\
2006 & 88,11 & 101,96 & 79,60 & 52,26 & 28,22 & 16,10 & 5,56 & 5,75 & 31,22 & 146,33 & 90,12 & 34,06 \\
2007 & 81,25 & 99,31 & 63,54 & 43,66 & 46,45 & 16,93 & 5,90 & 5,23 & 8,67 & 46,18 & 140,77 & 146,41 \\
2008 & 51,01 & 60,37 & 58,43 & 42,42 & 31,57 & 13,59 & 5,06 & 6,67 & 34,84 & 41,83 & 83,31 & 73,32 \\
2009 & 184,80 & 160,94 & 98,86 & 46,93 & 45,96 & 17,56 & 6,95 & 4,38 & 32,03 & 58,61 & 100,11 & 222,19 \\
2010 & 187,31 & 157,97 & 50,00 & 52,92 & 30,99 & 23,50 & 6,79 & 4,29 & 15,59 & 82,20 & 37,26 & 206,07 \\
2011 & 117,68 & 92,97 & 75,10 & 94,72 & 68,03 & 33,43 & 4,82 & 4,34 & 16,66 & 56,73 & 47,05 & 120,85 \\
2012 & 224,77 & 124,21 & 57,97 & 42,39 & 55,97 & 15,33 & 5,85 & 5,39 & 8,06 & 85,94 & 96,82 & 240,97 \\
2013 & 106,20 & 89,58 & 63,70 & 70,76 & 50,96 & 17,44 & 6,69 & 5,66 & 17,49 & 56,84 & 58,00 & 54,94 \\
2014 & 106,89 & 44,71 & 92,61 & 33,11 & 57,63 & 31,47 & 5,84 & 5,98 & 38,65 & 70,06 & 88,89 & 139,08 \\
2015 & 160,13 & 133,54 & 117,00 & 37,54 & 50,30 & 24,59 & 6,49 & 8,33 & 21,95 & 63,04 & 29,48 & 26,20 \\
2016 & 115,93 & 56,13 & 70,94 & 30,44 & 60,06 & 22,95 & 7,72 & 6,99 & 22,81 & 16,45 & 54,28 & 158,20 \\
2017 & 108,01 & 21,38 & 98,96 & 59,02 & 58,83 & 18,86 & 5,64 & 7,41 & 10,01 & 51,05 & 81,61 & 65,94 \\
2018 & 166,49 & 85,99 & 76,02 & 32,92 & 64,85 & 56,20 & 6,08 & 6,03 & 17,29 & 63,20 & 80,22 & 223,19 \\
2019 & 218,82 & 103,56 & 90,39 & 63,59 & 28,17 & 37,78 & 9,29 & 5,26 & 13,65 & 33,70 & 59,54 & 184,44 \\
\hline
\end{tabular}

According to the data obtained in the study, the amount of rainfall is minimum in 2008 and maximum in 2009 (Figure 5). In Figure 6 average precipitation value map of 2010 is given.

\subsection{Analysis of temperature values}

In the study, temperature changes were investigated based on yearly average temperatures. The data obtained are shown in Table 4.

According to the data obtained in the study, the lowest temperature was seen in 2008 with $-0.45 \mathrm{C}^{\circ}$. The highest temperature was seen in 2010 with $26.3 \mathrm{C}^{\circ}$.

According to the data obtained in the study, the average yearly temperature graph between 2004-2019 is shown in Figure 7.

According to the data obtained in the study, based on the years 2004 and 2019, the average temperature is $14.31 \mathrm{C}^{\circ}$.
Besides, the average temperature in 2010and 2018 show a significant increase. In Figure 8 average temperature value map of 2010 is given.

\subsection{Analysis of land surface temperature values}

The daily average land surface temperature values observed in the Mediterranean region between the years 2004-2019 obtained in the study are shown in Table 5.

According to the land surface temperature data obtained between 2004-2019, the average is $21.81 \mathrm{C}^{\circ}$. Figure 9 shows the yearly average land surface temperature values between 2004-2019.

When the results are analyzed, the highest values are seen in 2008 and 2016 while the lowest value is seen in 2011. 


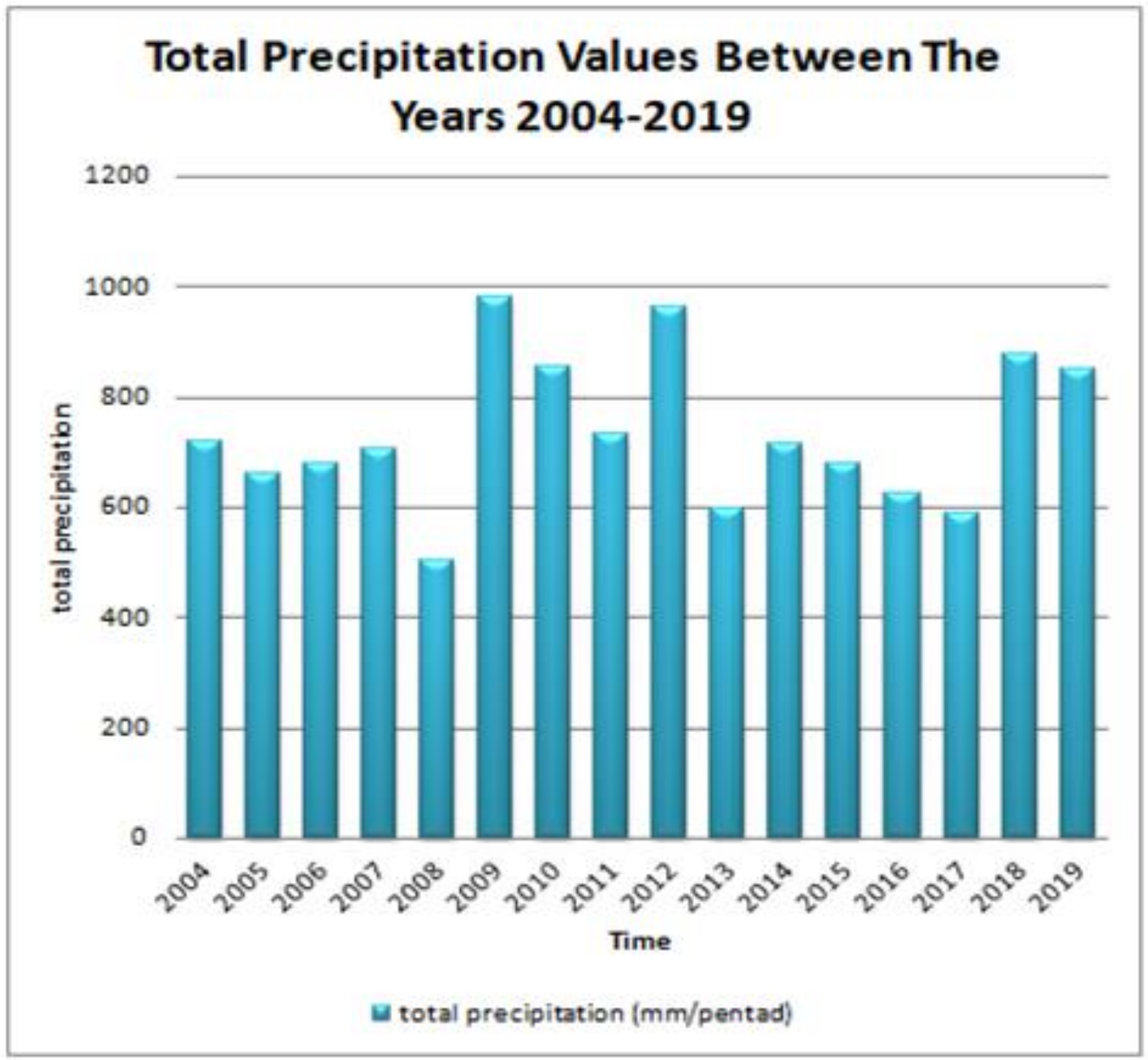

Figure 5. Total precipitation by years in the Mediterranean Region

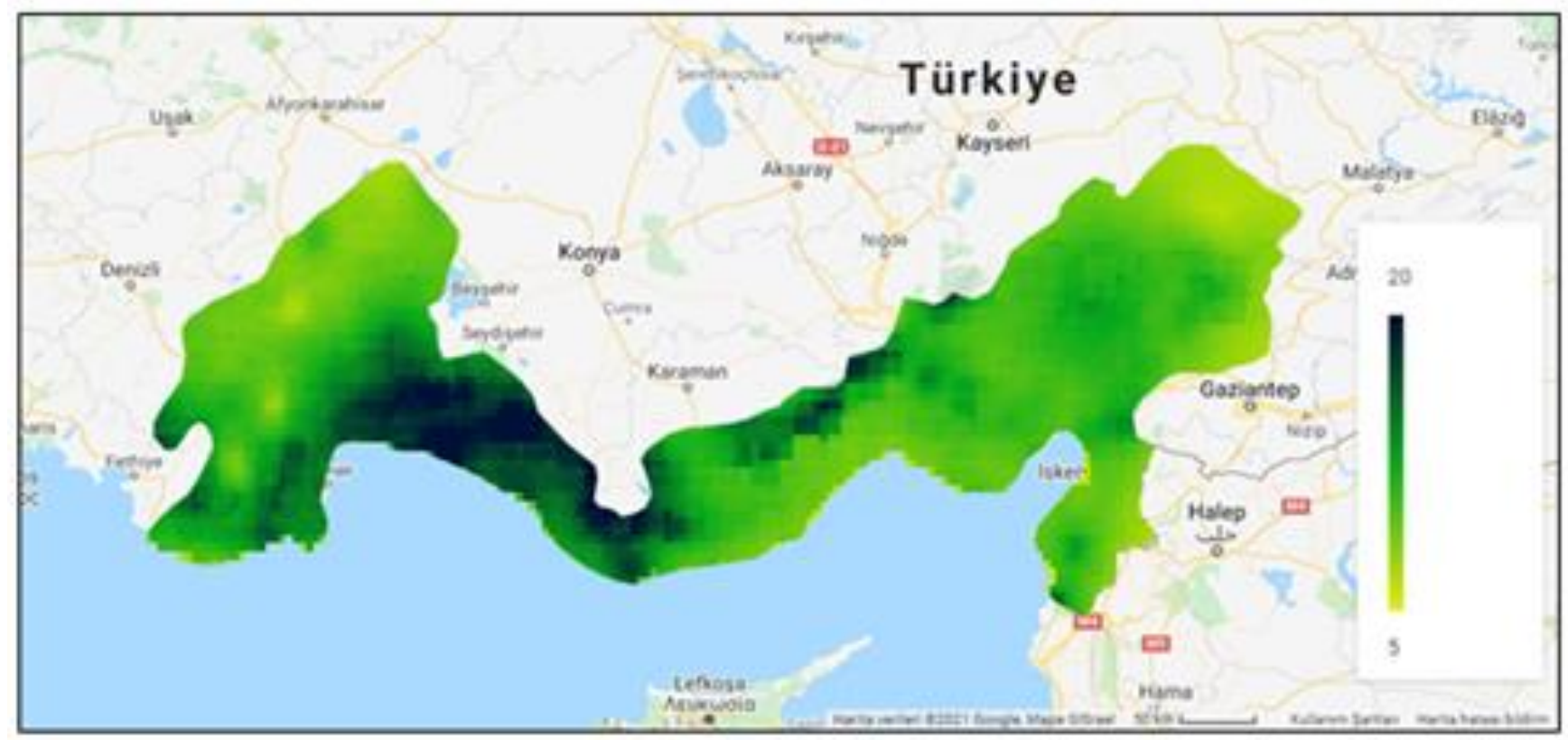

Figure 6. Average precipitation values map of 2010 
Table 4. Monthly average temperature values

\begin{tabular}{ccccccccccccc}
\hline & Jan & Feb & March & Apr & May & Jun & Jul & Aug & Sep & Oct & Nov & Dec \\
\hline 2004 & 1,36 & 2,61 & 7,84 & 11,13 & 15,35 & 20,26 & 23,87 & 23,19 & 20,23 & 16,29 & 8,50 & 3,17 \\
2005 & 3,40 & 2,72 & 7,21 & 11,55 & 15,76 & 19,70 & 24,19 & 24,10 & 19,30 & 12,74 & 7,14 & 5,12 \\
2006 & 1,13 & 3,57 & 7,25 & 12,22 & 15,95 & 21,13 & 23,22 & 25,31 & 19,86 & 14,69 & 7,21 & 3,07 \\
2007 & 2,04 & 3,53 & 7,36 & 9,71 & 17,76 & 21,60 & 25,04 & 24,79 & 20,51 & 15,63 & 8,68 & 3,24 \\
2008 & $-0,45$ & 1,40 & 9,54 & 13,19 & 15,39 & 21,53 & 24,51 & 25,34 & 20,06 & 14,49 & 10,13 & 3,84 \\
2009 & 3,32 & 4,21 & 5,76 & 11,07 & 15,33 & 21,19 & 23,63 & 23,35 & 18,84 & 16,49 & 8,68 & 6,65 \\
2010 & 4,67 & 5,80 & 9,36 & 12,05 & 16,84 & 20,05 & 24,56 & 26,30 & 21,82 & 14,70 & 11,88 & 7,14 \\
2011 & 3,14 & 3,90 & 6,79 & 10,27 & 14,42 & 19,55 & 24,12 & 23,88 & 20,67 & 13,01 & 5,13 & 3,58 \\
2012 & 0,83 & 0,52 & 4,55 & 12,37 & 15,09 & 21,89 & 25,20 & 24,07 & 21,35 & 15,71 & 10,40 & 5,18 \\
2013 & 2,99 & 5,60 & 7,86 & 12,28 & 17,54 & 20,79 & 23,57 & 24,15 & 19,41 & 12,81 & 10,44 & 1,85 \\
2014 & 4,96 & 5,77 & 8,52 & 12,24 & 15,60 & 19,84 & 24,08 & 24,88 & 19,39 & 14,34 & 8,38 & 7,27 \\
2015 & 2,41 & 4,06 & 7,57 & 10,03 & 16,32 & 18,88 & 23,81 & 24,36 & 22,42 & 16,32 & 10,45 & 4,32 \\
2016 & 1,86 & 7,80 & 8,77 & 14,62 & 15,60 & 21,80 & 24,92 & 25,10 & 19,84 & 16,23 & 8,88 & 1,41 \\
2017 & 0,31 & 3,27 & 7,95 & 11,59 & 15,53 & 20,79 & 25,43 & 24,30 & 22,25 & 14,66 & 8,66 & 6,54 \\
2018 & 4,01 & 7,14 & 10,48 & 14,33 & 17,58 & 20,52 & 24,30 & 24,52 & 21,54 & 15,63 & 10,00 & 5,38 \\
2019 & 2,76 & 5,06 & 7,55 & 10,45 & 17,68 & 21,36 & 23,27 & 24,34 & 20,81 & 17,13 & 11,06 & 5,69 \\
\hline
\end{tabular}

\section{The Average Temperature Values Between The Years 2004-2019}

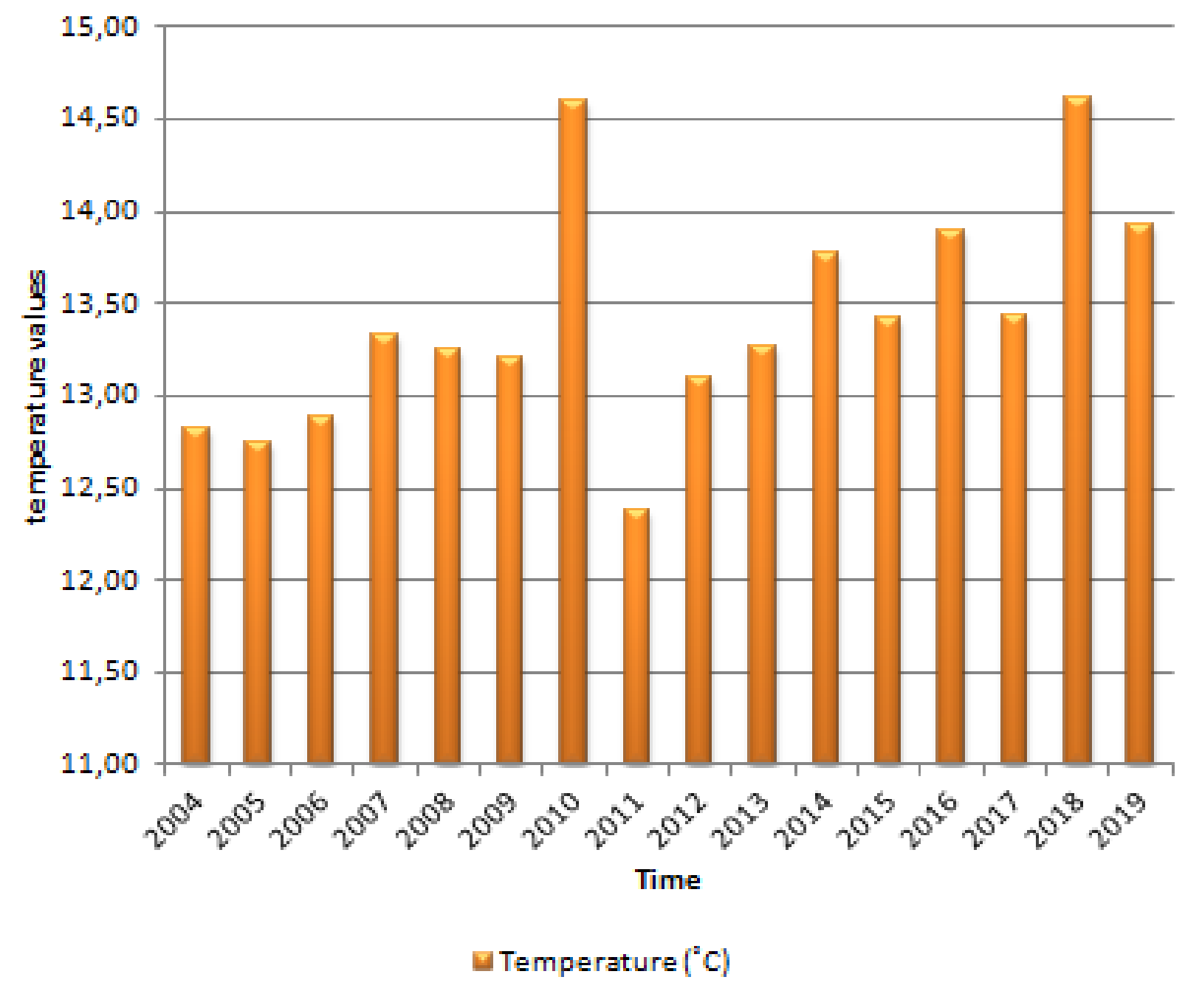

Figure 7. Average temperature values of the Mediterranean Region between 2004-2019 


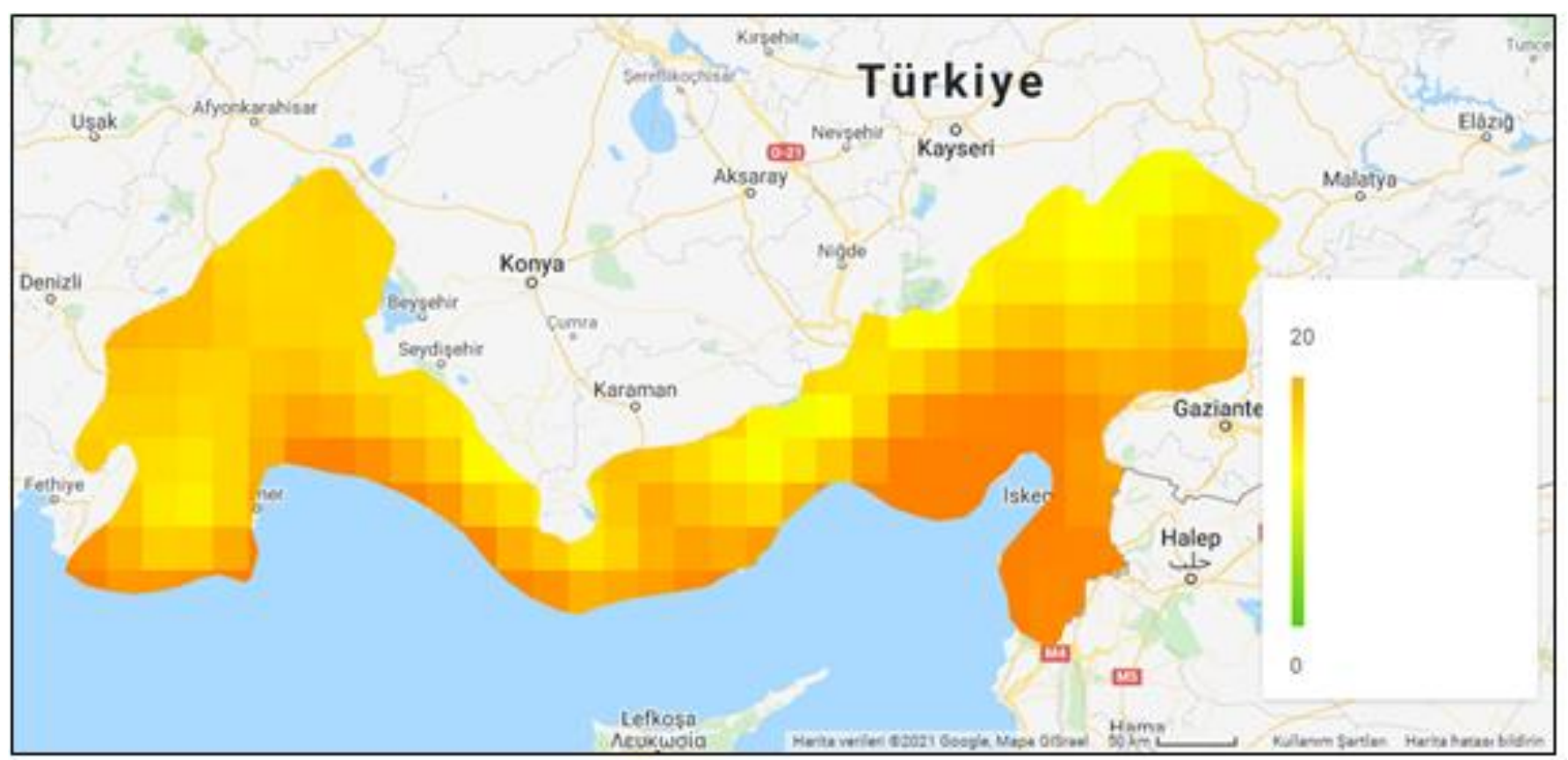

Figure 8. Average temperature values map of 2010

Table 5. Monthly land surface temperature values

\begin{tabular}{lllllllllllll}
\hline & Jan & Feb & March & Apr & May & Jun & Jul & Aug & Sep & Oct & Nov & Dec \\
\hline 2004 & 2,81 & 7,89 & 17,56 & 23,43 & 27,12 & 32,93 & 36,99 & 34,93 & 32,22 & 24,82 & 11,20 & 7,87 \\
2005 & 6,88 & 8,06 & 16,18 & 23,56 & 29,20 & 32,43 & 36,32 & 35,65 & 29,62 & 19,43 & 12,28 & 8,75 \\
2006 & 5,25 & 9,12 & 16,12 & 21,49 & 29,79 & 33,68 & 35,43 & 36,20 & 30,12 & 18,49 & 13,98 & 8,92 \\
2007 & 7,12 & 8,64 & 16,49 & 23,25 & 28,29 & 34,06 & 38,18 & 36,31 & 32,06 & 22,18 & 11,70 & 7,31 \\
2008 & 6,31 & 9,12 & 17,87 & 24,12 & 27,95 & 34,49 & 37,49 & 36,31 & 28,99 & 21,50 & 14,93 & 8,53 \\
2009 & 6,65 & 8,00 & 15,31 & 21,31 & 28,45 & 33,62 & 35,06 & 35,68 & 28,00 & 22,32 & 14,16 & 8,92 \\
2010 & 7,79 & 9,74 & 18,81 & 22,37 & 28,70 & 31,24 & 35,95 & 37,08 & 31,35 & 20,31 & 18,04 & 10,67 \\
2011 & 6,70 & 11,68 & 15,87 & 19,81 & 25,04 & 29,93 & 35,04 & 35,14 & 30,37 & 18,74 & 11,95 & 8,04 \\
2012 & 2,81 & 4,87 & 16,12 & 23,87 & 25,46 & 33,56 & 36,99 & 35,70 & 32,37 & 22,43 & 14,33 & 8,98 \\
2013 & 6,68 & 11,57 & 16,74 & 24,12 & 26,87 & 32,56 & 36,12 & 35,98 & 29,82 & 22,79 & 15,12 & 7,74 \\
2014 & 9,75 & 13,56 & 18,18 & 23,37 & 26,87 & 31,18 & 34,93 & 35,49 & 28,18 & 19,43 & 12,56 & 10,15 \\
2015 & 5,51 & 8,01 & 16,18 & 22,31 & 27,37 & 29,06 & 35,23 & 34,62 & 31,03 & 21,98 & 15,62 & 10,64 \\
2016 & 4,92 & 16,18 & 17,62 & 25,68 & 26,12 & 32,43 & 36,87 & 35,57 & 29,99 & 23,14 & 15,73 & 5,29 \\
2017 & 1,39 & 10,56 & 18,49 & 23,31 & 25,62 & 32,62 & 37,00 & 34,98 & 31,30 & 21,18 & 13,39 & 10,15 \\
2018 & 8,07 & 12,45 & 18,37 & 25,43 & 26,75 & 30,62 & 34,62 & 35,31 & 30,56 & 21,81 & 13,37 & 6,74 \\
2019 & 3,34 & 10,32 & 15,37 & 19,68 & 27,72 & 31,34 & 34,33 & 34,93 & 31,30 & 25,62 & 17,10 & 9,42 \\
\hline
\end{tabular}

\subsection{Analysis of aerosol optical depth values}

In the study, the data obtained from satellites and the densities of harmful substances in the air were examined over the years. The aerosol optical depth values are seen in the Mediterranean region between the years 20042019 are shown in Table 6.

According to the data obtained in the study, the average annual aerosol optical depth between 20042019 is 0.22 . The highest aerosol optical depth was seen in 2007 and 2009 with 0.37 . The lowest aerosol optical depth was seen in 2005 with 0.1 . In Figure 10, the average aerosol optical depth chart for the Mediterranean Region 2004-2019 is shown.

According to the data obtained in the study highest average aerosol optical depth was seen in 2007 and 2009 with 0.24 . The lowest average aerosol optical depth was seen in 2005 with 0.19 .

\subsection{Analysis of ozone values}

The ozone values obtained in the study between 2004 and 2019 in the Mediterranean Region are shown in Table 7.

When the ozone averages between 2004 and 2019 are evaluated, the highest value was seen in April 2010 with 370.78. The lowest ozone average was seen in November 2010 with 263.92. Figure 11 shows the average annual ozone graph for the Mediterranean region for 2004-2019.

When the obtained values are analyzed, it is seen that the minimum annual average value seen in 2008 . 


\section{Average Land Surface Temperature Values Between The Years 2004-2019}

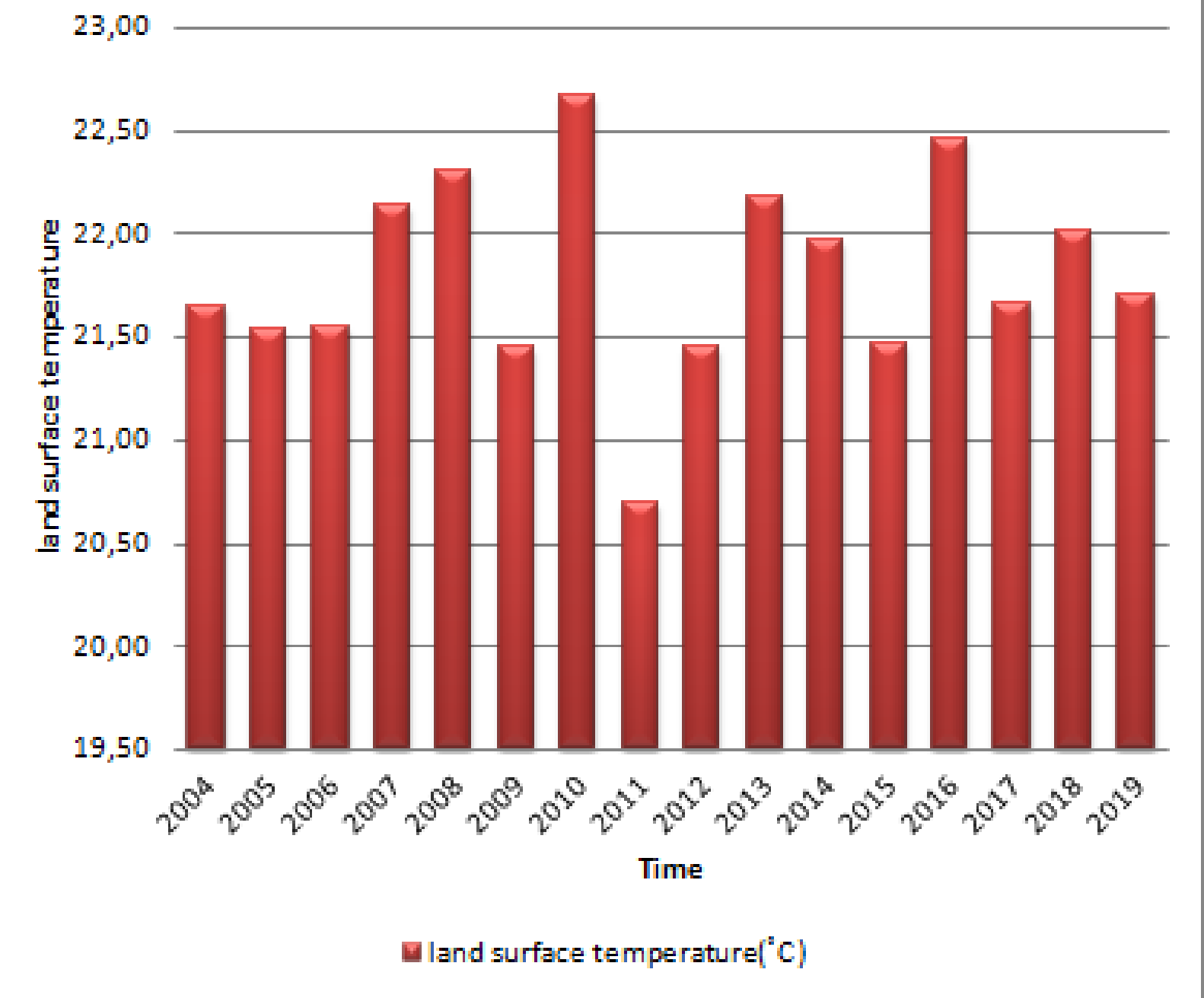

Figure 9. Mediterranean Region average land surface temperature for the years 2004-2019

Tablo 7. Monthly Ozone Values

\begin{tabular}{ccccccccccccc}
\hline & Jan & Feb & March & Apr & May & Jun & Jul & Aug & Sep & Oct & Nov & Dec \\
\hline 2004 & 331,55 & 331,37 & 321,09 & 344,93 & 335,70 & 320,38 & 298,96 & 293,94 & 280,43 & 279,53 & 291,51 & 303,88 \\
2005 & 318,07 & 337,22 & 341,85 & 341,46 & 336,92 & 316,11 & 292,05 & 283,12 & 275,28 & 279,21 & 282,45 & 290,34 \\
2006 & 321,94 & 324,66 & 351,10 & 333,39 & 333,83 & 302,00 & 293,30 & 281,49 & 279,67 & 290,68 & 299,37 & 302,87 \\
2007 & 317,72 & 338,89 & 353,88 & 369,66 & 325,77 & 311,38 & 289,95 & 278,23 & 271,08 & 282,30 & 287,19 & 296,78 \\
2008 & 313,48 & 327,61 & 317,40 & 317,21 & 334,72 & 306,92 & 292,19 & 271,72 & 270,39 & 282,14 & 282,42 & 295,06 \\
2009 & 314,92 & 338,02 & 362,36 & 356,82 & 334,08 & 316,10 & 298,13 & 281,96 & 288,47 & 277,51 & 280,96 & 310,11 \\
2010 & 328,87 & 347,53 & 343,34 & 370,78 & 348,34 & 325,47 & 297,95 & 282,88 & 287,87 & 283,92 & 263,92 & 295,27 \\
2011 & 332,67 & 338,53 & 342,96 & 351,55 & 328,00 & 304,32 & 287,18 & 274,44 & 272,50 & 272,55 & 290,75 & 289,71 \\
2012 & 329,87 & 332,79 & 357,13 & 324,36 & 332,24 & 305,37 & 294,61 & 280,38 & 268,64 & 279,57 & 285,75 & 298,09 \\
2013 & 324,81 & 312,78 & 323,03 & 344,62 & 326,97 & 311,70 & 295,73 & 281,01 & 283,26 & 287,56 & 277,94 & 319,32 \\
2014 & 316,66 & 321,80 & 334,05 & 339,49 & 334,71 & 317,58 & 292,93 & 277,38 & 275,69 & 285,70 & 286,19 & 291,77 \\
2015 & 329,09 & 351,63 & 341,26 & 363,81 & 338,32 & 316,63 & 293,47 & 286,01 & 269,84 & 286,98 & 286,21 & 305,77 \\
2016 & 322,92 & 322,64 & 344,79 & 331,27 & 335,69 & 297,21 & 289,06 & 284,77 & 271,98 & 272,27 & 281,97 & 335,50 \\
2017 & 343,77 & 348,98 & 348,07 & 344,30 & 334,00 & 315,21 & 293,71 & 275,07 & 264,00 & 274,61 & 306,58 & 283,45 \\
2018 & 338,27 & 333,34 & 331,45 & 345,52 & 333,53 & 314,01 & 293,08 & 281,24 & 280,49 & 280,28 & 288,01 & 304,62 \\
2019 & 322,56 & 332,76 & 337,21 & 356,72 & 326,96 & 309,17 & 298,74 & 291,35 & 287,99 & 283,79 & 284,11 & 318,09 \\
\hline
\end{tabular}




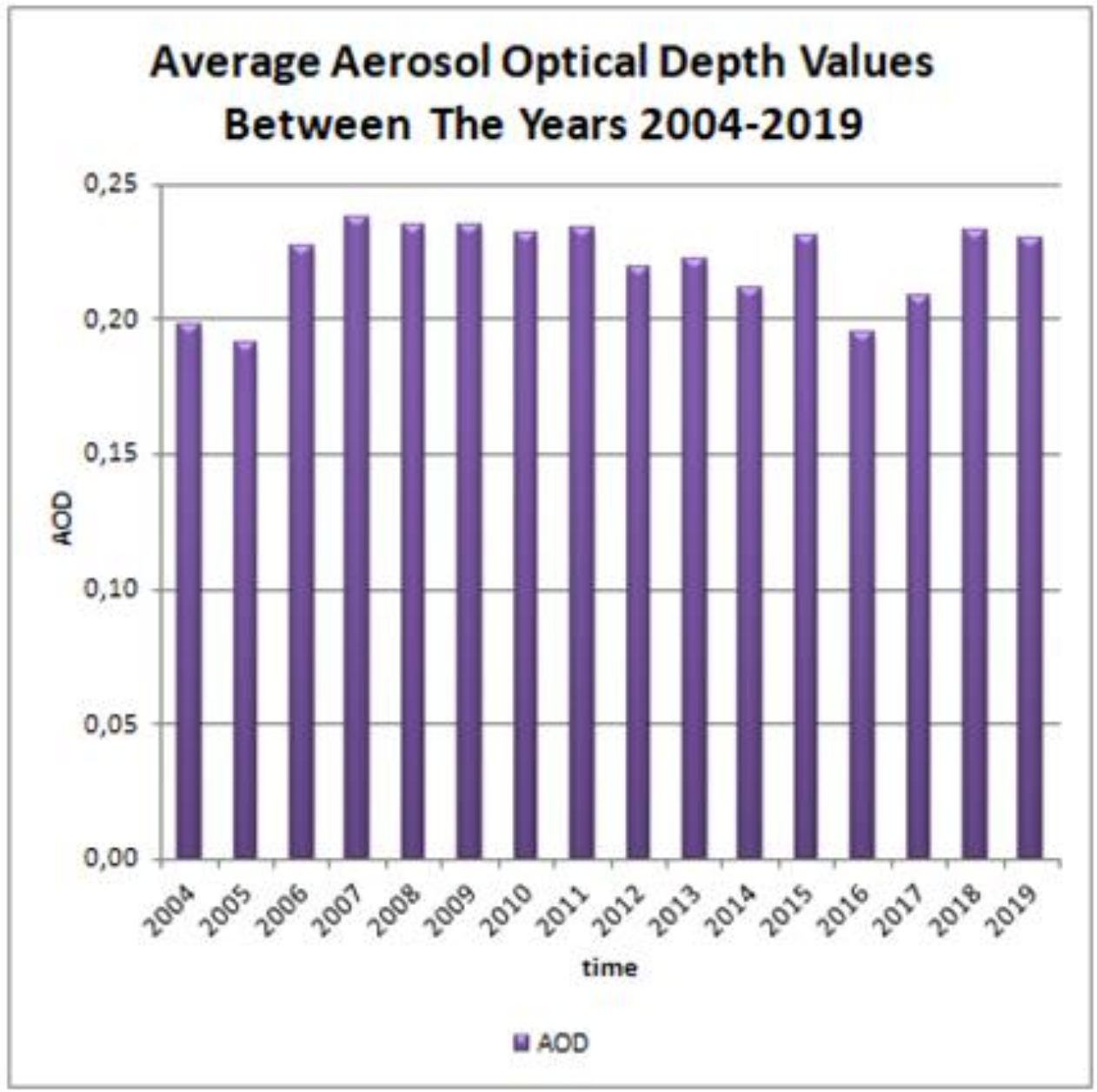

Figure 10. Mediterranean region 2004-2019 average aerosol optical depth values

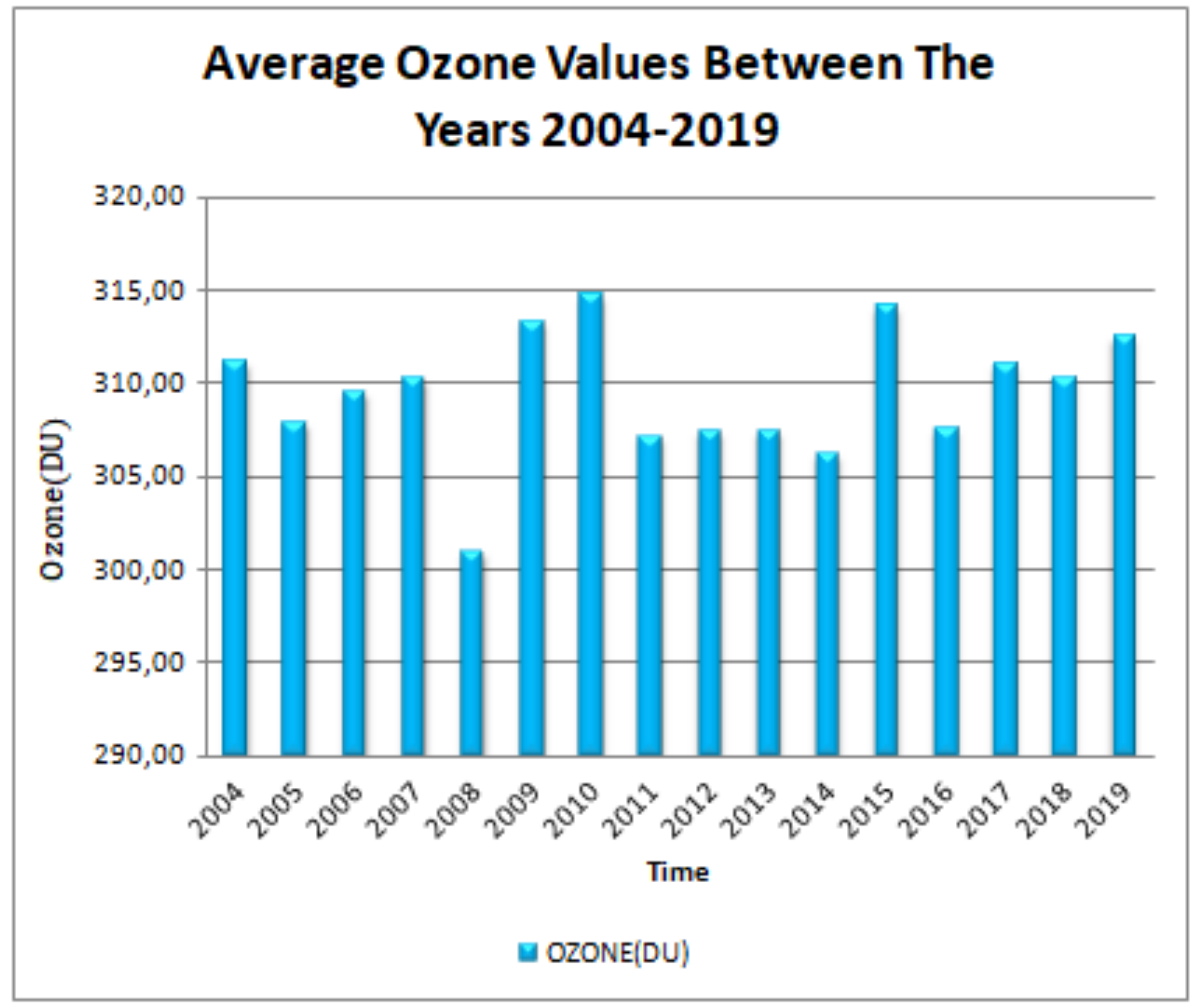

Figure 11. Mediterranean Region average ozone values for 2004-2019 


\subsection{Analysis of population data}

In the study, population data in the Mediterranean region were examined using TUIK Data. The data obtained are given in Figure 12.

When the data are examined, it is seen that there is an increase in the population in the Mediterranean region.

\subsection{Analysis of forest fires}

In the study, the areas and dates of forest fires were obtained from Hansen Global Forest Change v1.7 data by using GEE. It is seen that most of the fires occurred in the summer months. In the study, it was observed that approximately 216134 hectares of forest area were lost between 2004-2019 (Figure 13).

The area lost because of forest fires between 2004 and 2019 obtained by using the General Directorate of Forestry data (OGM, 2020). The obtained values are shown in Figure 14.

When the obtained data analyzed the maximum forest area loss because of the fires is observed in 2008 while the minimum loss in 2005.

According to the General Directorate of Forestry data, the provinces with the most frequent fires are Antalya, Adana, Mersin, and Kahramanmaraş. According to the Antalya General Directorate of Forestry data, 29745 hectares of the area were lost between 2004-2019 in forest fires in Antalya. According to the Adana Regional Directorate of Forestry data, 5695 hectares of land were lost between 2004-2019 in forest fires in Osmaniye and Adana. According to the Mersin General Directorate of Forestry data, 9431 hectares of land were lost between 2004-2019 because of forest fires in Mersin. The most severe loss was experienced in the fire in 2008, with
5080 hectares. According to Kahramanmaraş Regional Directorate of Forestry, 10631 hectares of land were lost between 2004-2019 in forest fires in Kahramanmaraș and Hatay. The most severe loss was experienced in the fire in 2013, with 3669 hectares. According to the Isparta Regional Directorate of Forestry data, 1344 hectares of the area were lost between 2004-2019 in forest fires in Isparta and Burdur. The most severe loss was experienced in the fire in 2013, with 297 hectares (OGM, 2020).

\subsection{Multiple regression analysis}

In the study, data on NDVI, precipitation, temperature, land surface temperature, aerosol optical depth, ozone, population, forest losses between 20042019 were analyzed, and the results were evaluated. A multiple regression statistical model was used to investigate the effects of the obtained results on forest losses. For conducting multiple regression analysis, NDVI, precipitation, temperature, land surface temperature, aerosol optical depth, ozone, population, forest fires are used as independent variables and the forest losses were used as dependent variable. When the results of multiple linear regression are examined, it has been observed that population, and forest fire parameters have a significant effect on forest losses. The regression model obtained from the regression analysis is given by Eq. 1 .

$$
Y^{\prime}=-3 E+0,8+(42.85 * \text { Population })+(3601.18 * \text { Forest_Fires })
$$

In this regression model, it was found that the effect of independent variables on the dependent variable was calculated as $96 \%$.

\section{0}

\section{Population Data Between the Years 2004-2019}

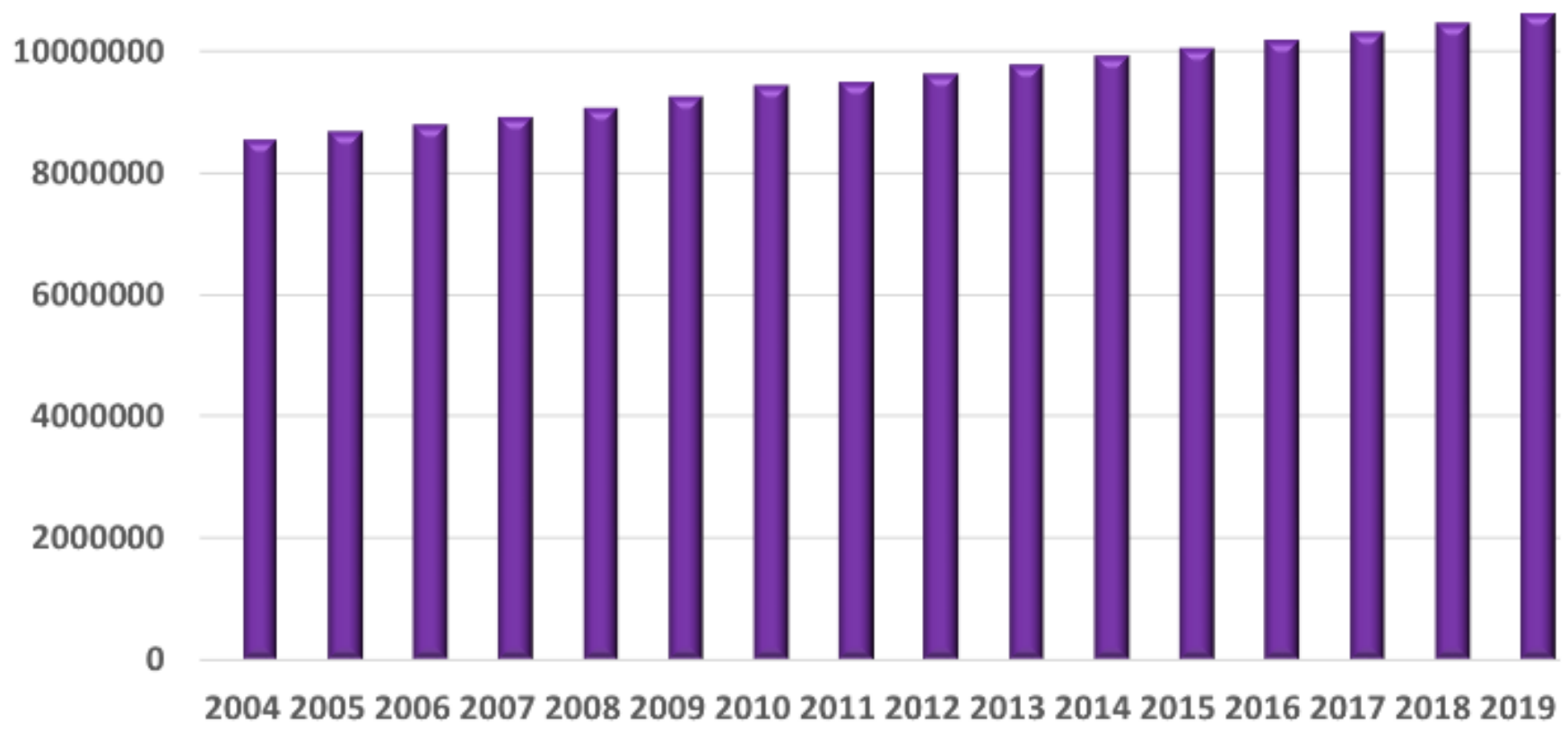

Figure 12. Population data of the Mediterranean Region for the years 2004-2019 


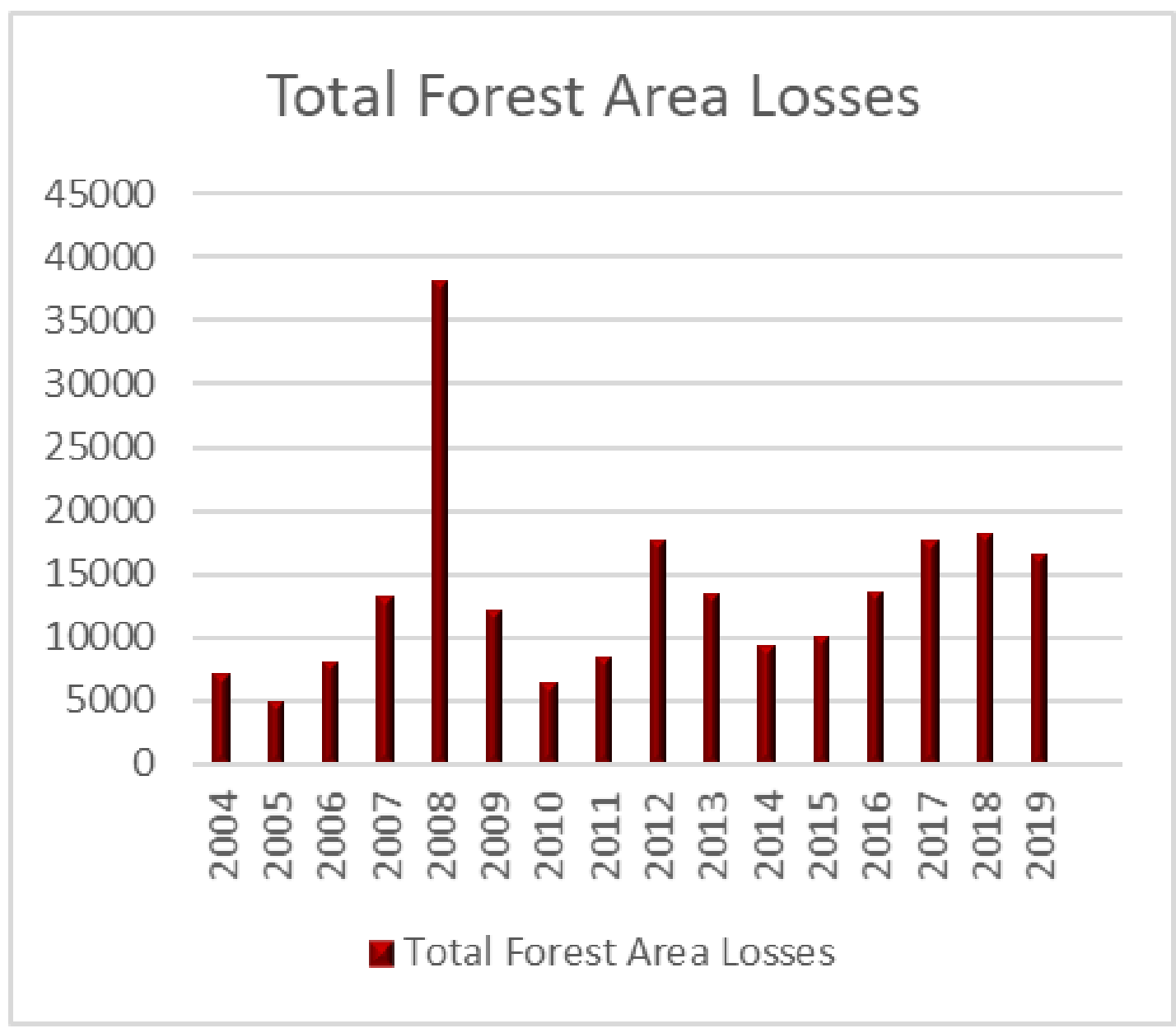

Figure 13. Total Forest Area Losses

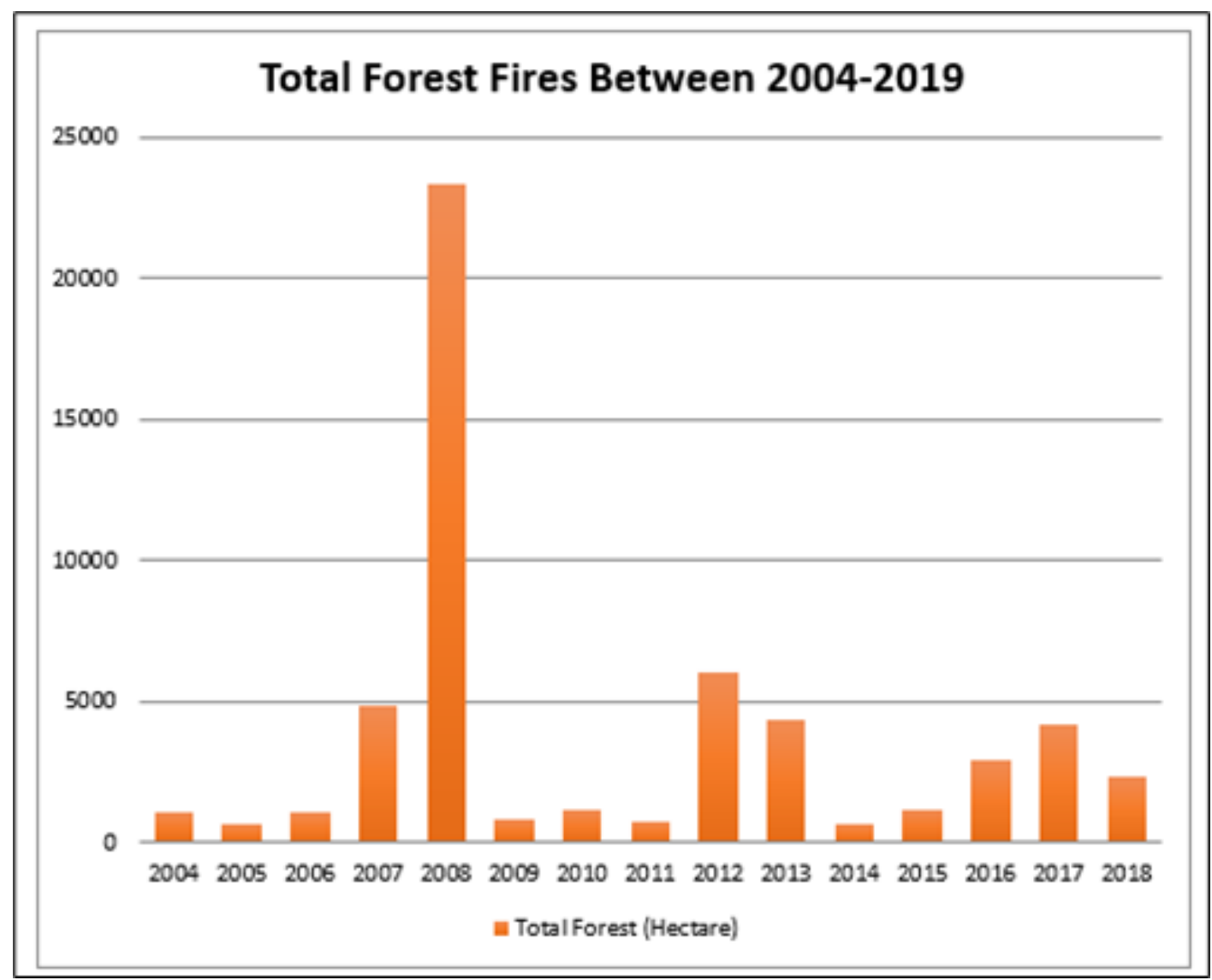

Figure 14. Total Forest Fire 


\section{DISCUSSION}

Within the scope of the study, forest losses in the Mediterranean Region have been examined in a versatile way, and many criteria that may affect these losses have been analyzed and evaluated by GEE data sets and code editor. Within the scope of the study, NDVI, precipitation, temperature, land surface temperature, aerosol optical depth, ozone, population, forest fires, and forest losses data were calculated between 2004-2019 and analyzed by multiple regression among the data. The effects of NDVI, precipitation, temperature, land surface temperature, aerosol optical depth, ozone, population, and forest fires independent variables on forest losses, dependent variables, were investigated. When the

Forest fires are among the most important causes of losses in forest areas. According to data from Turkey
General Directorate of Forestry, the number of fires between 1988 to 2019 is 66168 . The most of the fires are located in the Aegean and Mediterranean Regions (OGM, 2020).

In Figure 15, the comparison chart of total forest area losses and lost areas because of forest fires is given.

In Mediterranean region, the most forest area loss was experienced in 2008. According to the forest fires data of the Regional Directorate of Forestry, the most severe loss due to fires between 2004-2019 was seen in Antalya (OGM, 2020). According to the results, the year when forest fires were most common is 2008. According to the results, the year that lost the most area due to forest fires is 2008. The year that lost the most area due to reasons other than fire is 2018.

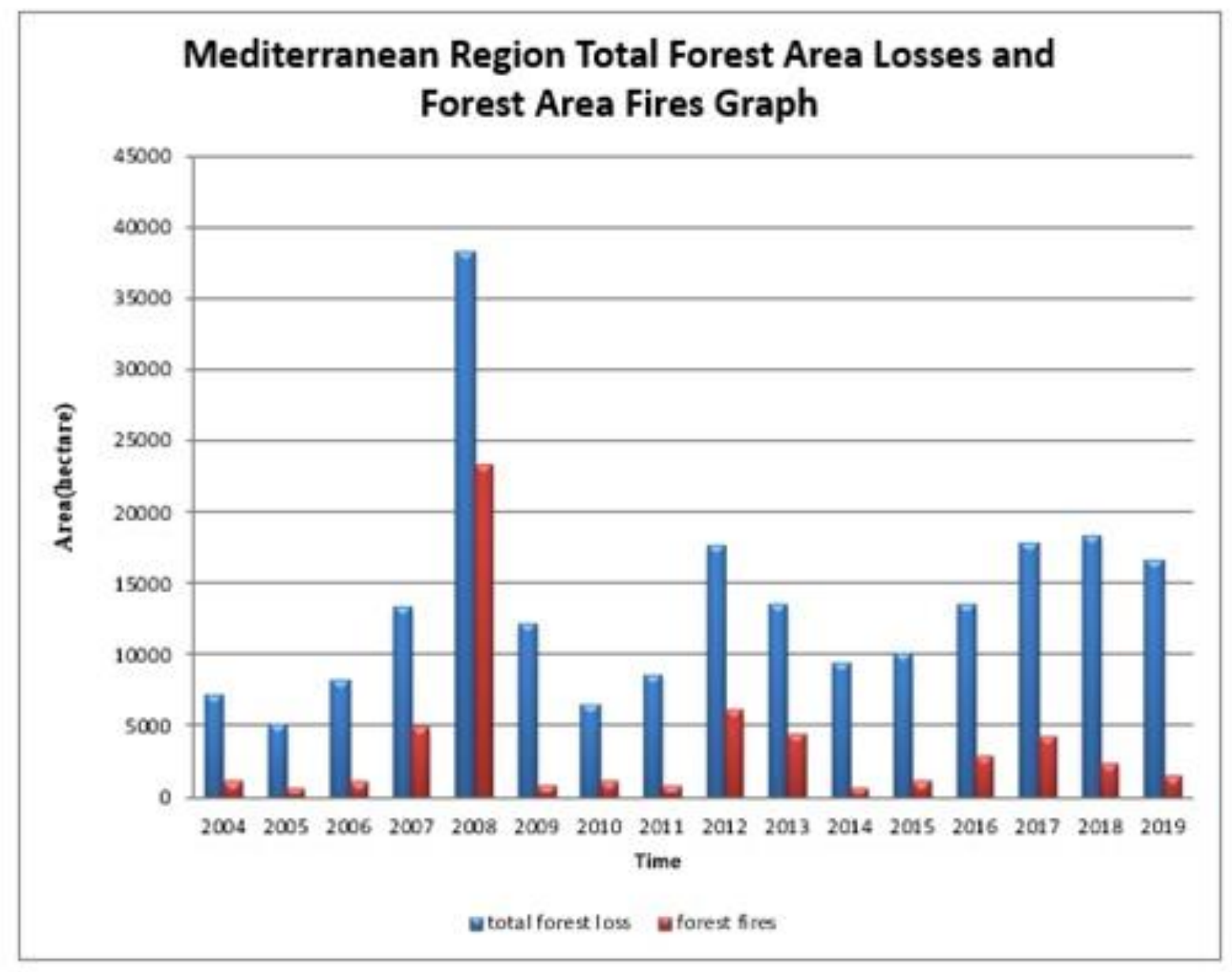

Figure 15. Mediterranean Region total forest area losses and loses areas because of forest fires

\section{CONCLUSION}

Deforestation is one of today's environmental problems that cause various harmful consequences. Rapidly increasing forest losses in recent years reveal the magnitude of the problem. For this reason, monitoring the temporal change in forest areas is of great importance in terms of future planning. With the monitoring of the temporal changes of forest areas, the causative factors should also be investigated.
In this study, the change of forest areas in the Mediterranean region was examined with GEE. Besides, the factors that are stated to cause forest loss in the literature have been investigated, and the values of these factors over the years in the Mediterranean region have been analyzed. All these data obtained were analyzed statistically, and the parameters that had a significant impact on forest losses in the area were determined.

The results show that this analysis method can greatly benefit decision-makers in simulating future 
forest change with a time series analysis of these data, designing and implementing appropriate regulatory actions to protect forests.

\section{Author contributions}

Neşe Başaran: Original draft preparation, Methodology, Software, Writing Dilek Küçük Matcı: Methodology, Writing-Reviewing and Editing. Uğur Avdan: Methodology, Writing-Reviewing and Editing.

\section{Conflicts of interest}

The authors declare no conflicts of interest.

\section{REFERENCES}

Ahady A B \& Kaplan G (2022). Classification comparison of Landsat- 8 and Sentinel-2 data in Google Earth Engine, study case of the city of Kabul. International Journal of Engineering and Geosciences, 7(1), 24-31.

Andrée B P J, Chamorro A, Spencer P, Koomen E \& Dogo $H$ (2019). Revisiting the relation between economic growth and the environment; a global assessment of deforestation, pollution and carbon emission. Renewable and Sustainable Energy Reviews, 114, 109221.

Atmış E \& Günşen H B (2016). Kentleşmenin Türkiye ormancılı̆̆ının dönüşümüne etkisi (1990-2010 Dönemi). Journal of the Faculty of Forestry Istanbul University, 66(1), 16-29.

Avdan U, Kucuk Matci D, Kaplan G, Yigit Avdan Z, Erdem F, Demirtas I \& Mizık E T (2021). Evaluating the Atmospheric Correction Impact on Landsat 8 and Sentinel-2 Data for Soil Salinity Determination. Geodetski list, 75(3), 255-240.

Betts M G, Wolf C, Ripple W J, Phalan B, Millers K A, Duarte A, . . . Levi T (2017). Global forest loss disproportionately erodes biodiversity in intact landscapes. Nature, 547(7664), 441-444.

Çömert R, Matci Küçük D \& Avdan U (2019). Object Based Burned Area Mapping with Random Forest Algorithm. International Journal of Engineering and Geosciences, 4(2), 78-87.

DeFries R S, Rudel T, Uriarte M \& Hansen M (2010). Deforestation driven by urban population growth and agricultural trade in the twenty-first century. Nature Geoscience, 3(3), 178-181.

del Castillo E M, García-Martin A, Aladrén L A L \& de Luis $M$ (2015). Evaluation of forest cover change using remote sensing techniques and landscape metrics in Moncayo Natural Park (Spain). Applied geography, 62, 247-255.

Demir N (2020). NDVI Analysis of Australian Bushfires with Cloud Computing. Türk Uzaktan Algilama ve CBS Dergisi, 1(2), 78-84.

Desbureaux S \& Damania R (2018). Rain, forests and farmers: Evidence of drought induced deforestation in Madagascar and its consequences for biodiversity conservation. Biological Conservation, 221, 357-364.

Doğaner S (2015). Akdeniz Bölgesi Coğrafyası. İstanbul: İ.Ü Edebiyat Fakültesi Coğrafya Bölümü.
Dündar C, Oğuz K \& Güllü G (2015). Aerosol Optik Derinliği Verilerinin Türkiye Íçin Alansal ve Zamansal Değișimlerin İzlenmesi. Paper presented at the VII. Uluslararası Katılımlı Atmosfer Bilimleri Sempozyumu, İstanbul.

Fearnside P M (1995). Potential impacts of climatic change on natural forests and forestry in Brazilian Amazonia. Forest Ecology and Management, 78(1-3), 51-70.

Funk C, Peterson P, Landsfeld M, Pedreros D, Verdin J, Shukla S, . . Hoell A (2015). The climate hazards infrared precipitation with stations-a new environmental record for monitoring extremes. Scientific data, 2(1), 1-21.

Gasparri N I \& Grau H R (2009). Deforestation and fragmentation of Chaco dry forest in NW Argentina (1972-2007). Forest Ecology and Management, 258(6), 913-921.

Hansen M C, Potapov $\mathrm{P}$ V, Moore R, Hancher M, Turubanova S A, Tyukavina A, Thau D, Stehman S V, Goetz S J, Loveland T R, Kommareddy A, Egorov A Chini L, Justice C O \& Townshend J R G (2013). HighResolution Global Maps of 21st-Century Forest Cover Change. Science, 850-853.

Hersbach H, Bell B, Berrisford P, Biavati G, Horányi A, Muñoz Sabater J, . . . Rozum I (2018). ERA5 hourly data on single levels from 1979 to present, Copernicus Climate Change Service (C3S) Climate Data Store (CDS). In.

Kaplan G, \& Avdan Z Y (2020). Space-borne air pollution observation from sentinel-5p tropomi: Relationship between pollutants, geographical and demographic data. International Journal of Engineering and Geosciences, 5(3), 130-137.

Khorrami B, Gunduz O, Patel N, Ghouzlane S \& Najjar M (2019). Land surface temperature anomalies in response to changes in forest cover. International Journal of Engineering and Geosciences, 4(3), 149-156.

Koskinen J, Leinonen U, Vollrath A, Ortmann A, Lindquist E, d'Annunzio R, . . . Käyhkö N (2019). Participatory mapping of forest plantations with Open Foris and Google Earth Engine. Isprs Journal of Photogrammetry and Remote Sensing, 148, 63-74.

Loreau M, Naeem S, Inchausti P, Bengtsson J, Grime J, Hector A, . . . Schmid B (2001). Biodiversity and ecosystem functioning: current knowledge and future challenges. Science, 294(5543), 804-808.

Matcı D K \& Avdan U (2020). Comparative analysis of unsupervised classification methods for mapping burned forest areas. Arabian Journal of Geosciences, 13(15), 1-13.

Ocer N E, Kaplan G, Erdem F, Kucuk Matci D \& Avdan U (2020). Tree extraction from multi-scale UAV images using Mask R-CNN with FPN. Remote sensing letters, 11(9), 847-856.

OGM (2020). Orman Yanginlarl. Retrieved from https://www.ogm.gov.tr/Sayfalar/OrmanYanginlari. aspx

Orhan 0, Dadaser-Celik F \& Ekercin S (2019). Investigating land surface temperature changes using Landsat-5 data and real-time infrared thermometer measurements at Konya closed basin in Turkey. 
International Journal of Engineering and Geosciences, 4(1), 16-27.

Pellikka P K, Lötjönen M, Siljander M \& Lens L (2009). Airborne remote sensing of spatiotemporal change (1955-2004) in indigenous and exotic forest cover in the Taita Hills, Kenya. International Journal of Applied Earth Observation and Geoinformation, 11(4), 221232.

Platnick S, King M \& Hubanks P (2017). MODIS Atmosphere L3 Monthly Product. NASA MODIS Adaptive Processing System, Goddard 730 Space Flight Center. last access: 3 December 2018.

Praticò S, Solano F, Di Fazio S \& Modica G (2021). Machine Learning Classification of Mediterranean Forest Habitats in Google Earth Engine Based on Seasonal Sentinel-2 Time-Series and Input Image Composition Optimisation. Remote Sensing, 13(4), 586.

Roces-Díaz J V, Vayreda J, Banqué-Casanovas M, Cusó M, Anton M, Bonet J A, ... de Aragón J M (2018). Assessing the distribution of forest ecosystem services in a highly populated Mediterranean region. Ecological indicators, 93, 986-997.

Sari F (2021). Forest fire susceptibility mapping via multi-criteria decision analysis techniques for Mugla, Turkey: A comparative analysis of VIKOR and TOPSIS. Forest Ecology and Management, 480, 118644.

Schepaschenko D, Shvidenko A, Lesiv M Y, Ontikov P, Shchepashchenko M \& Kraxner F (2015). Estimation of forest area and its dynamics in Russia based on synthesis of remote sensing products. Contemporary Problems of Ecology, 8(7), 811-817.
Şen G, Güngör E \& Şevik H (2018). Defining the effects of urban expansion on land use/cover change: a case study in Kastamonu, Turkey. Environmental monitoring and assessment, 190(8), 1-13.

TOB (2019). Çölleşmeyle Mücadele. Retrieved from http://cmusep.cem.gov.tr/Uploads/Documents/CM USEP_baski_versiyonu-pdf(eylemplani).pdf

Tolunay D (2013). Ormanlar ve Íklim Değişikliği. İstanbul: IÜ Orman Fakültesi Toprak İlmi ve Ekoloji Anabilim Dall.

Tolunay D (2015). Türkiye'de Ormansızlașma İe Kaybedilen Karbon Miktarlarl. Paper presented at the 6. Ulusal Hava Kirliliği ve Kontrolü Sempozyumu2015 7-9 Ekim 2015, İzmir.

TUIK (2021). TUIK Veri Portalı. Retrieved from https://data.tuik.gov.tr/Kategori/GetKategori?p=Nu fus-ve-Demografi-109

Wan Z (1999). MODIS Land-Surface Temperature Algorithm Theoretical Basis Document. NASA Earth Data. $\quad$ Retrieved from https://lpdaac.usgs.gov/products/mod11a2v006/

Xiong J, Thenkabail P S, Tilton J C, Gumma M K, Teluguntla P, Oliphant A, . . G Gorelick N (2017). Nominal 30-m cropland extent map of continental Africa by integrating pixel-based and object-based algorithms using Sentinel-2 and Landsat-8 data on Google Earth Engine. Remote Sensing, 9(10), 1065.

Yu Z, Yao Y, Yang G, Wang X \& Vejre H (2019). Strong contribution of rapid urbanization and urban agglomeration development to regional thermal environment dynamics and evolution. Forest Ecology and Management, 446, 214-225. 